\title{
UJI DAYA HAMBAT BERBAGAI KONSENTRASI PERASAN JERUK LEMON TERHADAP BAKTERI PROPIONIBACTERIUM ACNES
}

\author{
Kadek Eliana Kesuma Dewi ${ }^{1}$, Nur Habibah², Nyoman Mastra ${ }^{3}$ \\ 1,2,3 Jurusan Analis Kesehatan, Politeknik Kesehatan Kemenkes Denpasar \\ e-mail: nur.habibah.poltekkesdps@gmail.com
}

\begin{abstract}
Abstrak
Propionibacterium acnes merupakan salah satu bakteri yang menyebabkan terjadinya jerawat. Salah satu cara untuk mengatasi jerawat yaitu dengan memanfaatkan buah jeruk lemon. Beberapa penelitian terdahulu melaporkan bahwa jeruk lemon memiliki kandungan bahan aktif, antara lain karotenoid dan flavonoid yang memiliki aktivitas antibakteri. Penelitian ini bertujuan untuk mengetahui kemampuan daya hambat berbagai konsentrasi perasan jeruk lemon terhadap pertumbuhan bakteri Propionibacterium acnes. Penelitian ini merupakan eksperimen murni dengan rancangan penelitian Posttest Only Control Design menggunakan metode difusi cakram Kirby Bauer dengan enam konsentrasi perasan buah jeruk lemon yaitu 5 , $12,5,25,50,75$, dan $100 \%$. Kontrol kerja yang digunakan adalah kloramfenikol $30 \mu \mathrm{g}$ dan kontrol negatifnya adalah akuades steril. Hasil penelitian menunjukkan bahwa perasan buah jeruk lemon mampu menghambat pertumbuhan bakteri Propionibacterium acnes dengan rerata zona hambat berturut-turut yaitu sebesar 7,$15 ; 9,20 ; 11,25 ; 12,50 ; 14,10$ dan $16,90 \mathrm{~mm}$ dan termasuk ke dalam kategori zona hambat sedang dan kuat. Berdasarkan hasil penelitian yang diperoleh, dapat disimpulkan bahwa masing-masing konsentrasi perasan jeruk lemon memiliki kemampuan yang berbeda-beda terhadap pertumbuhan Propionibacterium acnes.
\end{abstract}

Kata kunci: Perasan Jeruk Lemon, Propionibacterium Acnes, Zona Hambat

\begin{abstract}
Propionibacterium acnes is one if the several bacteria that can cause acne. One of the ways to resolve this infection of bacterium is to use lemon. Some previous research was reported that lemon contains carotenoids and flavonoids, which has potential effect to use as antibacterial agent. This research was conducted to study the potential effect of the various concentration of lemon juice to inhibits the growth of Propionibacterium acnes bacteria. This study is a true experiment with the Posttest Only Control Design, using Kirby Bauer diffusion disc method with six different concentration, there were $5,12,5,25,50,75$, and $100 \%$. The positive and negative control is used $30 \mu \mathrm{g}$ of chloramphenicol and sterile aquadest. The results proved that lemon juice was able to inhibit the growth of Propionibacterium acnes bacteria with the diameter of inhibition zone of $5,12,5,25,50,75$, and $100 \%$ concentration is 7,15 ; 9,20; 11,25; 12,50; 14,10 and 16,90 mm, respectively. These diameter inhibition zones were classified as medium and strong inhibitory effect category. Based on these results it can be concluded that various concentration of lemon juice have different inhibition effect against the growth of Propionibacterium acnes bacteria.
\end{abstract}

Keywords : Lemon Juice, Propionbacterium Acnes, Inhibition Zone

\section{PENDAHULUAN}

Kulit merupakan organ terluar yang berfungsi sebagai garis pertahanan terluar dari serangan infeksi sehingga mengakibatkan kulit sangat mudah terkena berbagai paparan zat kimia fisika dari lingkungan. Dampak dari hal tersebut adalah munculnya kelainan kulit. Kelainan kulit yang paling umum terjadi di seluruh dunia adalah jerawat atau dalam bahasa medisnya disebut acne vulgaris (AV). Hampir setiap orang pernah mengalami 
jerawat (Afifi dan Erlin, 2017). Jerawat cukup merisaukan karena berhubungan dengan menurunnya kepercayaan diri akibat berkurangnya keindahan wajah penderita (Andy, 2009).

Prevalensi penderita jerawat di Indonesia terus meningkat, tahun 2006 sebanyak $60 \%$, tahun 2007 sebanyak $80 \%$, dan tahun 2009 sebanyak 90\%. Prevalensi penderita jerawat di Indonesia berkisar $80-85 \%$ pada remaja dengan puncak insidens usia 15-18 tahun, 12\% pada usia $>25$ tahun dan $3 \%$ pada usia 35-44 tahun (Afriyanti, 2015).

Salah satu penyebab terjadinya jerawat yaitu karena infeksi bakteri. Propionibacterium acnes merupakan bakteri yang menyebabkan terjadinya jerawat yang tergolong dalam kelompok bakteri Corynebacteria. Propionibacterium acnes adalah flora normal kulit terutama di wajah yang pertumbuhannya relatif lambat, termasuk ke dalam bakteri gram positif anaerob, namun dihubungkan dengan kondisi kulit yang berjerawat (Rusli, Rasyad, dan Nugraha, 2016).

Propionibacterium acnes mampu merusak stratum corneum dan germinat pada kulit. Bakteri Propionibacterium acnes menggunakan sebum yang diproduksi di folikel sebagai sumber utama makanan. Dengan menggunakan enzim khusus, bakteri ini menghasilkan asam lemak bebas melalui hidrolisis trigliserida kelenjar sebasea oleh lipasenya. Asam lemak ini dapat mengakibatkan inflamasi jaringan ketika berhubungan dengan sistem imun dan mendukung terjadinya jerawat (Khan, Assi, dan Moore, 2009).

Saat ini telah banyak dilakukan pengobatan terhadap jerawat salah satunya dengan cara menurunkan jumlah koloni Propionibacterium acnes yaitu dengan memberikan antibiotik seperti Eritromisin, Klindamisin, Tetrasiklin dan bahan-bahan kimia seperti Sulfur, Resorsinol, Asam Salisilat, Benzoil Peroksida dan Asam Azelat (Hidayah, 2016).

Bahaya dari resistensi bakteri dan biaya pengobatan yang cukup tinggi mendorong pengembangan sumber obat dari bahan alam yang dapat menggantikan peran obat antibakteri sintetik (Afifi dan Erlin, 2017). Penggunaan obat yang berasal dari bahan alam dinilai lebih aman dari resiko efek samping dibandingkan dengan obatobatan sintetik. Selain itu, harga obat yang berasal dari bahan alam relative lebih terjangkau dibandingkan dengan obat-obatan sintetik (Handayani, 2009).

Salah satu bahan alam yang memiliki potensi sebagai antibakteri adalah jeruk lemon. Jeruk lemon dimanfaatkan dihampir semua rumah tangga di Asia Tenggara terutama sebagai penambah rasa masakan serta menghilangkan bau amis, pembuatan minuman, dan berbagai macam obat tradisional. Buah jeruk lemon dilaporkan mengandung banyak senyawa bioaktif seperti asam sitrat, flavonoid, saponin, limonoid, tanin, dan terpenoid (Handayani, 2009). Berdasarkan uraian tersebut, penelitian ini dilakukan untuk mengetahui kemampuan antibakteri perasan jeruk lemon.

\section{METODE}

Penelitian ini merupakan true experiment dengan rancangan penelitian Posttest Only Control Design dengan menggunakan metode difusi cakram Kirby Bauer. Penelitian ini dilakukan di Laboratorium Mikrobiologi Jurusan Analis Kesehatan. Penelitian ini menggunakan perasan jeruk lemon dengan enam konsentrasi yang berbeda, antara lain 5 , $12,5,25,50,75$, dan 100\%. Kontrol negatif yang digunakan adalah akuades steril sedangkan kontrol positif menggunakan kloramfenikol $30 \mu \mathrm{g}$. Pada penelitian ini dilakukan dengan empat kali pengulangan

Data rerata diameter zona hambat diperoleh dengan cara mengukur zona bening yang terbentuk di sekeliling cakram dengan menggunakan jangka sorong. Selanjutnya, data yang diperoleh diuji secara statistik dengan uji Kolmogorov Smirnov untuk mengetahui distribusi data. Jika data berdistribusi normal, uji dilanjutkan dengan uji One Way Anova dan uji Least Significant Difference (LSD).

Tahap pengujian dimulai dari pengambilan koloni Propionibacterium acnes dengan menggunakan ose. 
Selanjutnya, dibuat suspensi bakteri menggunakan $\mathrm{NaCl}$ fisiologis 0,95\% sebanyak $5 \mathrm{ml}$ kemudian dihomogenkan sampai diperoleh kekeruhan 0,5 Mc Farland. Suspensi bakteri Propionibacterium acnes kemudian diinokulasikan secara merata pada media MHA. Sebanyak $20 \mu \mathrm{L}$ jeruk lemon pada berbagai konsentrasi diteteskan pada cakram disk kosong, kemudian diletakkan pada cawan petri. Sebagai kontrol positif digunakan cakram kloramfenikol $30 \mu \mathrm{g}$ dan kontrol negatif digunakan akuades steril. Selanjutnya, cawan petri diinkubasi selama 24 jam pada suhu $37^{\circ} \mathrm{C}$. Uji daya hambat ditentukan berdasarkan zona bening yang terbentuk disekitar kertas cakram pada cawan petri.

\section{HASIL DAN PEMBAHASAN}

\section{Hasil}

a. Diameter zona hambat pada kelompok kontrol

Berdasarkan hasil penelitian, diperoleh rerata diameter zona hambat pada kelompok kontrol kerja yaitu sebesar sebesar $28,50 \mathrm{~mm} \pm 0,5$ dan kontrol negatif tidak membentuk zona hambat. Pada kelompok control negatif dengen menggunakan akuades steril, diketahui bahwa tidak terbentuk diameter zona hambat di sekeliling cakram.

Rerata diameter zona hambat pada berbagai konsentrasi perasan buah jeruk lemon terhadap pertumbuhan bakteri Propionibacterium acnes disajikan dalam Tabel 1.

Tabel 1. Data Diameter Zona Hambat Berbagai Konsenrasi Perasan Buah Jeruk Lemon Terhadap Pertumbuhan Bakteri Propionibacterium acnes

\begin{tabular}{cccccc}
\hline \multirow{2}{*}{ Konsentrasi } & \multicolumn{4}{c}{ Diameter Zona Hambat (mm) } & \multirow{2}{*}{ Rerata \pm SD } \\
\cline { 2 - 5 } & I & II & III & IV & \\
\hline $5 \%$ & 7,10 & 7,20 & 7,10 & 7,20 & $7,15 \pm 0,05$ \\
$12,5 \%$ & 9,20 & 9,20 & 9,30 & 9,10 & $9,20 \pm 0,1$ \\
$25 \%$ & 11,30 & 11,20 & 11,20 & 11,30 & $11,25 \pm 0,05$ \\
$50 \%$ & 12,50 & 12,50 & 12,50 & 12,50 & $12,50 \pm 0,0$ \\
$75 \%$ & 14,00 & 14,20 & 14,20 & 14,00 & $14,10 \pm 0,1$ \\
$100 \%$ & 17,00 & 16,80 & 16,80 & 17,00 & $16,90 \pm 0,1$ \\
Kontrol (-) & 0 & 0 & 0 & 0 & 0 \\
\hline
\end{tabular}

\section{Pembahasan}

a. Analisis data

Hasil pengukuran diameter zona hambat yang diperoleh selanjutnya dianalisis menggunakan uji statistik. Uji pertama yang dilakukan yaitu uji Kolmogorov Smirnov (KS) untuk menguji distribusi data. Hasil uji KS menunjukkan bahwa nilai $p=0,895$. Bila dibandingkan dengan nilai $\alpha(0,05)$, maka $p>\alpha$. Hal ini menunjukkan bahwa data diameter zona hambat pertumbuhan bakteri Propionibacterium acnes berdistribusi normal. Uji selanjutnya yaitu uji One Way Anova. Pada uji One Way Anova diperoleh nilai $p(0,000)<\alpha(0,05)$ yang menunjukkan bahwa ada perbedaan diameter zona hambat pertumbuhan bakteri Propionibacterium acnes pada berbagai konsentrasi perasan buah jeruk lemon. Untuk mengetahui perbedaan zona hambat yang bermakna antara masing-masing konsentrasi, maka dilanjutkan dengan uji LSD (Least Significant Difference). Pada uji LSD diperoleh nilai $p(0,000)<\alpha(0,05)$ yang menunjukkan bahwa terdapat perbedaan nilai zona hambat yang bermakna pada masing-masing konsentrasi perasan buah jeruk lemon.

\section{b. Diameter zona hambat kontrol kerja}

Kontrol kerja yang digunakan dalam penelitian ini adalah antibiotik kloramfenikol $30 \mu \mathrm{g}$. Pemeriksaan menggunakan kontrol kerja ini bertujuan untuk mengetahui kebenaran metode dan prosedur pengujian yang dilakukan dalam suatu penelitian. Selain itu, kelompok kontrol kerja juga diperlukan untuk menilai kelayakan isolat bakteri uji yang 
digunakan, ketepatan konsentrasi suspensi bakteri dan untuk mengetahui media pertumbuhan yang digunakan dalam pengujian masih berada dalam kondisi yang baik. Berdasarkan hasil pengukuran, rerata diameter zona hambat kloramfenikol yang terbentuk yaitu 28,50 $\mathrm{mm}$. Jika dibandingkan dengan tabel NCCLS maka diameter zona hambat tersebut termasuk kategori sensitif dalam menghambat pertumbuhan bakteri Propionibacterium acnes.

\section{c. Diameter zona hambat kontrol negatif}

Dalam penelitian ini kontrol negatif yang digunakan adalah akuades steril. Pemeriksaan menggunakan kontrol negatif bertujuan untuk mengetahui pengaruh pelarut terhadap diameter zona hambat yang terbentuk pada masingmasing konsentrasi perasan buah jeruk lemon. Pada kelompok kontrol negatif, diketahui bahwa zona bening di sekitar cakarm tidak terbentuk. Hal ini membuktikan bahwa zona hambat yang terbentuk pada masing-masing konsentrasi perasan buah jeruk lemon tidak dipengaruhi oleh pelarut melainkan karena aktivitas senyawa aktif yang ada pada perasan buah jeruk lemon.

\section{d. Diameter zona hambat kelompok perlakuan \\ 1) Konsentrasi $5 \%$}

Rerata diameter zona hambat yang terbentuk pada konsentrasi $5 \%$ yaitu $7,15 \mathrm{~mm}$ dan merupakan rerata diameter zona hambat terkecil diantara rerata diameter zona hambat konsentrasi lainnya. Diameter zona hambat yang terbentuk termasuk dalam kategori daya hambat sedang. Berdasarkan penelitian yang dilakukan oleh Ali (2010), perasan jeruk lemon dengan konsentrasi 8\% mampu menghambat bakteri Shigella flexneri dengan zona hambat sebesar 6,6 $\mathrm{mm}$. Berdasarkan data tersebut, dapat diketahui bahwa perasan jeruk lemon pada konsentrasi $5 \%$ memiliki kemampuan yang lebih baik dalam menghambat pertumbuhan bakteri Propionibacterium acnes, dibuktikan dengan diameter zona hambat yang dihasilkan lebih luas, yaitu sebesar 7,15 $\mathrm{mm}$.
2) Konsentrasi $12,5 \%$

Perasan jeruk lemon dengan konsentrasi $12,5 \%$ mampu menghambat pertumbuhan bakteri Propionibacterium acnes dengan rerata diameter zona hambat sebesar 9,20 mm. Diameter zona hambat ini lebih besar bila dibandingkan dengan diameter zona hambat yang dihasilkan pada konsentrasi 5\%. Diameter zona hambat yang terbentuk, termasuk ke dalam kategori daya hambat sedang. Penelitian yang dilakukan oleh Hartin (2018) menunjukkan bahwa perasan jeruk lemon dengan konsentrasi $12,5 \%$ tidak mampu menghambat pertumbuhan bakteri Staphylococcus epidermidis. Berdasarkan data tersebut, dapat diketahui bahwa perasan jeruk lemon pada konsentrasi $12,5 \%$ memiliki kemampuan yang lebih baik dalam menghambat pertumbuhan bakteri Propionibacterium acnes.

3) Konsentrasi $25 \%$

Perasan jeruk lemon dengan konsentrasi $25 \%$ mampu menghambat pertumbuhan bakteri Propionibacterium acnes dengan rerata diameter zona hambat sebesar 11,25 mm. Diameter zona hambat ini lebih besar bila dibandingkan dengan diameter zona hambat konsentrasi 12,5\%. Diameter zona hambat yang terbentuk termasuk dalam kategori daya hambat kuat. Berdasarkan penelitian yang dilakukan oleh Bansode dan Chavan (2012), perasan jeruk lemon dengan konsentrasi $25 \%$ menghambat bakteri Shigella sonnei dengan zona hambat sebesar $4 \mathrm{~mm}$. Berdasarkan data tersebut, dapat diketahui bahwa perasan jeruk lemon pada konsentrasi $25 \%$ memiliki kemampuan yang lebih baik dalam menghambat pertumbuhan bakteri Propionibacterium acnes dibuktikan dengan diameter zona hambat yang dihasilkan lebih luas, yaitu sebesar 11,25 $\mathrm{mm}$.

\section{4) Konsentrasi $50 \%$}

Perasan jeruk lemon dengan konsentrasi $50 \%$ mampu menghambat pertumbuhan bakteri Propionibacterium acnes dengan rerata diameter zona hambat sebesar $12,50 \mathrm{~mm}$. Diameter 
zona hambat ini lebih besar bila dibandingkan dengan diameter zona hambat konsentrasi 25\%. Diameter zona hambat yang terbentuk termasuk dalam kategori daya hambat kuat. Berdasarkan penelitian yang dilakukan oleh Manzoor dkk (2013), perasan buah jeruk lemon konsentrasi $50 \%$ mampu menghambat bakteri dengan zona hambat sebesar 5,8 $\mathrm{mm}$. Bila dibandingkan dengan data tersebut, dapat diketahui bahwa bahwa perasan jeruk lemon pada konsentrasi $50 \%$ memiliki kemampuan yang lebih baik dalam menghambat pertumbuhan bakteri Propionibacterium acnes, dibuktikan dengan diameter zona hambat yang dihasilkan lebih luas, yaitu sebesar 12,50 $\mathrm{mm}$.

\section{5) Konsentrasi $75 \%$}

Perasan jeruk lemon dengan konsentrasi $75 \%$ mampu menghambat pertumbuhan bakteri Propionibacterium acnes dengan rerata diameter zona hambat sebesar $14,10 \mathrm{~mm}$. Diameter zona hambat ini lebih besar bila dibandingkan dengan diameter zona hambat konsentrasi $50 \%$. Diameter zona hambat yang terbentuk termasuk dalam kategori daya hambat kuat. Berdasarkan penelitian yang dilakukan oleh Berti (2015), perasan air jeruk lemon konsentrasi $80 \%$ mampu menghambat bakteri Porphyromonas gingivalis dengan zona hambat sebesar $4,31 \mathrm{~mm}$. Bila dibandingkan dengan data tersebut, dapat diketahui bahwa bahwa perasan jeruk lemon pada konsentrasi $75 \%$ memiliki kemampuan yang lebih baik dalam menghambat pertumbuhan bakteri Propionibacterium acnes, dibuktikan dengan diameter zona hambat yang dihasilkan lebih luas, yaitu sebesar 12,50 $\mathrm{mm}$.

\section{6) Konsentrasi $100 \%$}

Perasan jeruk lemon dengan konsentrasi $100 \%$ mampu menghambat pertumbuhan bakteri Propionibacterium acnes dengan rerata diameter zona hambat sebesar 16,90 $\mathrm{mm}$ dan merupakan rerata diameter zona hambat terbesar jika dibandingkan dengan rerata diameter zona hambat konsentrasi lainnya. Diameter zona hambat yang terbentuk termasuk dalam kategori daya hambat kuat. Berdasarkan penelitian yang dilakukan oleh Velu dkk (2014), perasan jeruk lemon dengan konsentrasi 100\% mampu menghambat bakteri Salmonella typhi dengan diameter zona hambat sebesar 7,3 $\mathrm{mm}$. Bila dibandingkan dengan data tersebut, dapat diketahui bahwa bahwa perasan jeruk lemon pada konsentrasi $100 \%$ memiliki kemampuan yang lebih baik dalam menghambat pertumbuhan bakteri Propionibacterium acnes, dibuktikan dengan diameter zona hambat yang dihasilkan lebih luas, yaitu sebesar 16,90 mm.

Berdasarkan data-data rerata diameter zona hambat yang diperoleh, diketahui bahwa perasan jeruk lemon memiliki kemampuan daya hambat yang lebih baik terhadap pertumbuhan bakteri Propionibacterium acnes, dibandingkan dengan jenis bakteri yang lain. Propionibacterium acnes merupakan bakteri gram positif sedangkan Shigella flexneri, Shigella sonnei, Escherichia coli, Porphyromonas gingivalis, dan Salmonella typhi merupakan bakteri gram negatif. Perbedaan zona hambat yang dihasilkan dimungkinkan terjadi karena adanya perbedaan respon akibat adanya perbedaan kepekaan bakteri gram positif dan negatif terhadap senyawa antibakteri yang diberikan. Bakteri gram positif cenderung lebih sensitif terhadap senyawa antibakteri daripada bakteri gram negatif karena struktur dinding sel bakteri gram positif lebih sederhana sehingga memudahkan senyawa antibakteri untuk masuk ke dalam sel bakteri gram positif (Kumayas, Wewengkang, dan Sudewi, 2015).

Diameter zona hambat yang diperoleh terhadap bakteri Propionibacterium acnes lebih besar, jika dibandingkan dengan bakteri Staphylococcus epidermidi. Hal ini dimungkinkan terjadi karena setiap jenis bakteri mempunyai sifat dan ketahanan yang berbeda-beda terhadap suatu bahan antibakteri, meskipun kedua bakteri tersebut sama-sama merupakan golongan bakteri gram positif. Bakteri Propionibacterium acnes memiliki sifat pertumbuhan bakteri (fase lag) yang lambat, berbeda dengan bakteri 
Staphylococcus

epidermidis.

Pertumbuhan bakteri Staphylo- coccus epidermidis yang ditanamkan pada suatu media lebih cepat dibandingkan dengan penetrasi senyawa antibakteri pada cakram kertas terhadap bakteri. Hal ini menyebabkan senyawa antibakteri tidak dapat menghambat pertumbuhan bakteri Staphylococcus epidermidis. Bakteri Staphylococcus epidermidis tergolong ke dalam galur bakteri yang tahan terhadap antimikroba, sehingga untuk menghambat pertumbuhannya diperlukan antimikroba yang lebih peka terhadap bakteri tersebut (Wahdanigsih, Untari, dan Fauziah, 2014).

Berdasarkan data yang diperoleh, diketahui pula bahwa diameter zona hambat yang dihasilkan oleh tiap-tiap konsentrasi perasan jeruk lemon tersebut tersebut berbeda-beda. Hal tersebut disebabkan karena perbedaan jumlah senyawa aktif pada tiap-tiap konsentrasi yang digunakan. Semakin tinggi konsentrasi maka semakin besar zona hambat yang terbentuk. Hal tersebut terjadi karena semakin tinggi konsentrasi maka semakin banyak senyawa aktif yang terkandung di dalamnya sehingga efektivitas dalam menghambat bakteri akan semakin meningkat dan menghasilkan zona hambat yang lebih luas.

Kemampuan perasan buah jeruk lemon dalam menghambat pertumbuhan bakteri dikarenakan senyawa aktif yang terkandung di dalamnya memiliki kemampuan antibakteri, antara lain adalah asam sitrat, flavonoid, saponin, terpenoid hingga limonoid. Berbagai jenis senyawa aktif tersebut memiliki mekanisme yang berbeda-beda dalam menghambat pertumbuhan bakteri. Asam sitrat membuat derajat keasaman $(\mathrm{pH})$ perasan buah jeruk lemon menjadi asam yang mengakibatkan $\mathrm{pH}$ internal sel bakteri menurun sehingga dapat mengganggu aktivitas sel bakteri dan pertumbuhan bakteri menjadi terhambat (Batubara, 2017).

Flavonoid memiliki kaktivitas sebagai senyawa antimkroba karena mampu membentuk senyawa kompleks dengan protein ekstraseluler, mengubah sifat fisik dan kimiawi sitoplasma dan mendenaturasi dinding sel bakteri melalui ikatan hidrogen. Aktivitas ini akan mengganggu fungsi permeabilitas selektif, fungsi pengangkutan aktif, dan pengendalian susunan protein sehingga menyebabkan kematian pada bakteri. Terganggunya dinding sel akan menyebabkan lisis pada sel (Ramadhinta, Nahzi, dan Budiarti, 2016). Saponin dapat menurunkan tegangan permukaan sel bakteri sehingga terjadi kebocoran sel bakteri dan mengakibatkan keluarnya senyawa intraseluler.

Saponin akan berdifusi melalui membran luar dan dinding sel yang rentan, lalu mengikat membran sitoplasma dan mengganggu dan mengurangi kestabilan sel bakteri. Hal ini menyebabkan sitoplasma bocor keluar dari sel yang mengakibatkan kematian bakteri (Ngajow, Abidjulu, dan Kamu, 2013).

Limonoid dapat mengubah permea- bilitas membran sel dan menghilangkan ion-ion dalam sel. Minyak atsiri bersifat lipofilik yang dapat melewati dinding bakteri karena dinding bakteri terdiri atas polisakarida, asam lemak, dan fosfolipid. Hal ini dapat mengakibatkan kerusakan dinding sel sehingga dapat membunuh bakteri (Dewi, 2015).

Aktivitas antibakteri terpenoid diduga melibatkan pemecahan membran oleh komponen - komponen lipofilik. Tanin merupakan senyawa yang dapat menghambat pertumbuhan bakteri dengan cara menghambat enzim reverse transkriptase dan DNA topoisomerase yang berfungsi pada proses transkripsi dan replikasi, sehingga sel bakteri tidak dapat terbentuk (Ngajow, Abidjulu, dan Kamu, 2013).

Berdasarkan data yang diperoleh tersebut, terbukti bahwa perasan jeruk lemon memiliki potensi yang cukup baik sebagai senyawa antibakteri karena kemampuannya yang cukup kuat dalam menghambat pertumbuhan bakteri, terutama bakteri Propionibacterium acnes. Berdasarkan daya hambat yang dihasilkan oleh masing-masing konsentrasi perasan buah jeruk lemon, dapat diketahui bahwa konsentrasi efektif yang dapat menghambat pertumbuhan bakteri Propionibacterium acnes yaitu sebesar $25 \%$, karena pada konsentrasi 
tersebut perasan jeruk lemon telah mampu menghambat pertumbuhan bakteri dengan kategori daya hambat kuat

\section{SIMPULAN}

Berdasarkan penelitian yang telah dilakukan dapat disimpulkan bahwa perasan buah jeruk lemon terbukti memiliki kemampuan sebagai bahan antibakteri terhadap bakteri Propionibacterum acnes.

Penelitian ini dapat dilanjutkan dengan melakukan pengujian kadar hambat dan kadar bunuh minimum serta pengujian lainnya untuk memaksimalkan pengembangan perasan jeruk lemon sebagai agen antibakteri.

\section{DAFTAR PUSTAKA}

Afifi, R. dan E. Erlin. 2017. 'Uji Anti Bakteri Ekstrak Daun Jambu Biji (Psidium guajava L ) Terhadap Zona Hambat Bakteri Jerawat Propionibacterium acnes Secara In Vitro'. Jurnal Kesehatan Bakti Tunas Husada. 17(2) : 321-330.

Afriyanti, R. N. 2015. 'Akne Vulgaris Pada Remaja'. J Majority. 4(6) : 102-109.

Ali, Z. M. 2010. 'Antagonism Activity of Citrus Fruit Juices on Some Pathogenic Bacteria'. Journal of Kerbala University. 8(3) : 123-128.

Andy. 2009. 'Pengetahuan Dan Sikap Remaja SMA Santo Thomas 1 Medan Terhadap Jerawat'. KTI. Universitas Sumatera Utara.

Bansode dan Chavan. 2012. 'Studies on Antimicrobial Activity and Phytochemical Analysis of Citrus Fruits Juice Against Selected Enteric Pathogens'. International Research Journal of Pharmacy. 3(11) : 122126.

Batubara, N. A. 2017. 'Efek Air Perasan Buah Jeruk Lemon (Citrus limon) Terhadap Laju Aliran, Nilai pH Saliva Dan Jumlah Koloni Staphylococcus aureus (In Vivo)'. Skripsi. Universitas Sumatera Utara.

Berti, P. L. 2015. 'Daya Antibakteri Air Perasan Buah Lemon (Citrus limon (L.) Burm.f.) Terhadap Porphyromonas Gingivalis Dominan Periodontitis (In Vitro)'. Skripsi. Universitas Muhammadiyah
Surakarta. Diakses tanggal 5 September 2018.

Dewi, D. N. S. 2015.'Aktivitas Antibakteri Minyak Atsiri Batang Sereh (Cymbopogon citratus) Terhadap Propionibacterium acnes Secara In Vitro'. Skripsi. Universitas Jember.

Djajadisastra, J., A. Mun'im, dan Dessy. 2009. 'Formulasi Gel Topikal Dari Ekstrak Nerii Folium Dalam Sediaan Anti Jerawat'. Jurnal Farmasi Indonesia. 4(4) : 210-216.

Handayani, V. 2009. 'Pengujian Aktivitas Antibakteri Ekstrak Etanol Daun Kersen (Muntingia calabura L.) Terhadap Bakteri Penyebab Jerawat'. Jurnal Fitofarmaka Indonesia. 2(1) : 94-96.

Hartin, E. 2018. 'Uji Efektivitas Antibakteri Perasan Jeruk Lemon (Citrus limon Linn) Terhadap Staphylococcus epidermidis'. Thesis. Universitas Muhammadiyah Sidoarjo.

Hidayah, N. 2016. 'Uji Aktivitas Ekstrak Metanol Klika Anak Dara ( Oblongus burm F.) Terhadap Bakteri Penyebab Jerawat'. Skripsi. Universitas Islam Negeri Alauddin.

Khan, Z. Z., M. Assi, dan T. A. Moore. 2009. 'Recurrent Epidural Abscess Caused by Propionibacterium acnes'. Kansas Journal of Medicine. 92-95.

Kumayas, A. R., D. S.Wewengkang,dan S. Sudewi. 2015. 'Aktifitas Antibakteri dan Karakteristik Gugus Fungsi Dari Tunikata Polycarpa Aurata'. Pharmacon Jurnal IImiah Farmasi. 4(1) : 32-44.

Manzoor, M., S. Naseer, R. Jabeen, dan M. Manzoor. 2013. 'Antibacterial Activity of Fruits Against Escherichia coli'. ARPN Journal of Agricultural and Biological Science. 8(3) : 258263.

Ngajow M., J. Abidjulu, V. S. dan Kamu. 2013. 'Pengaruh Antibakteri Ekstrak Kulit Batang Matoa (Pometia pinnata) Terhadap Bakteri Staphylococcus aureus Secara In Vitro'. Jurnal MIPA Unsrat Online. 2(2) : 128-132.

Ramadhinta, T. M., M. Y. I. Nahzi, dan L. Y. Budiarti. 2016. 'Uji Efektivitas Antibakteri Air Perasan Jeruk Nipis 
(Citrus Aurantifolia) Sebagai Bahan Irigasi Saluran Akar Alami Terhadap Pertumbuhan Enterococcus faecalis In Vitro'. DENTINO Jural Kedokteran Gigi. 1(2) :124-8.

Rusli, D., A. A. Rasyad, dan P. A. Nugraha. 2016. 'Formulasi Krim Clindamycin Sebagai Anti Jerawat dan Uji Efektivitas Terhadap Bakteri Propionibacterium acne'. Jurnal Ilmiah Bakti Farmasi. I(2) : 5-14.

Velu, S., F. A. Bakar, N. A. Mahyudin, N. Saari, dan M. Z. Zaman. 2014. 'In Vitro Antimicrobial Activity of Musk Lime, Key Lime and Lemon Extracts Against Food Related Pathogenic and Spoilage Bacteria'. International Food Research Journal. 21(1) : 379386. Wahdaningsih, S., E. K. Untari., dan Y. Fauziah. 2014. 'Antibakteri Fraksi n-Heksana Kulit Hylocereus polyrizus Terhadap Staphylococcus epidermidis dan Propionibacterium acnes'. Pharmaceutical Sciences and Research. 1(3) : 180-193. 